\title{
Kurumsal web sitelerinin işlevselliğinin, sunulan e- hizmetlerin ve halkla ilişkiler faaliyetlerinin içerik analizi yöntemiyle incelenmesi: Konya Büyükşehir Belediyesi web sitesi örneği
}

Şükran KARACA ${ }^{1}$

Araştırma Makalesi
Gönderi Tarihi:14.09.2020

Araştırma Makalesi
Gönderi Tarihi:14.09.2020 Kabul Tarihi: 23.11 .2020
Bahar Çiçek GÜBÜL²

DOI: https://doi.org/10.51177/kayusosder.794710

Online Yayın Tarihi: 31.12 .2020

\section{Özet}

Teknoloji kullanımının artmasıyla birlikte iletişime verilen önem de artmıştır. Kurumlar teknolojik gelişmeleri kullanarak kendi iletişim ağını oluşturmakta ve bu iletişim ağını kullanan kurumların başında ise belediyeler gelmektedir. Belediyeler web siteleri aracılığıyla e-hizmetler sunmakta, halkla yakından iletişim kurabilmekte, e-devlet ve e-belediye sistemini kullanarak iletişimi güçlendirmektedir. Bu bağlamda çalışmanın amacı, Konya Büyükşehir Belediyesi'nin web sitesinin işlevselliğinin, sunulan e-hizmetlerin ve halkla ilişkiler faaliyetlerinin içerik analizi yöntemiyle incelenmesidir. Çalışmada verilerin analiz edilmesinde Tanyıldızı ve Karatepe (2011) tarafından oluşturulmuş olan bir kodlama cetveli kullanılmış ve bu cetvele çeşitli eklemeler de yapılmıştır. Elde edilen bulgular doğrultusunda Konya Büyükşehir Belediyesi web sitesinin işlevsel ve sunulan ehizmetlerin ve halkla ilişkiler çalışmalarının genel olarak yeterli fakat bazı eksikliklerin de olduğu tespit edilmiştir. Çalışma sonucunda, web sitesi üzerinden sunulan e-hizmetlerin ve halkla ilişsiler çalışmalarının kalitesinin artırılması ve tespit edilen eksikliklerin giderilmesi için çeşitli önerilerde bulunulmuştur.

Anahtar Kelimeler: Konya Büyükşehir Belediyesi, E-Belediye, E-Hizmet, Web Sitesi, İçerik Analizi

\section{Functionality of corporate web sites, of e-services offered and analysis of public relations activities with content analysis: Konya Metropolitan Municipality web site example}

\begin{abstract}
With the increasing use of technology, the importance given to communication has increased. Institutions create their own communication network by using technological developments and municipalities are the leading institutions that use this communication network. Municipalities provide e-services through their websites, communicate closely with the public, and strengthen communication by using the e-government and emunicipality systems. In this context, the purpose of the study is to examine the functionality of the website of Konya Metropolitan Municipality, the offered e-services and public relations activities with the content analysis method. In the analysis of the data in the study, a coding scale created by Tany1ldizi and Karatepe (2011) was used and various additions were made to this scale. In line with the findings obtained, it has been determined that the functional and offered e-services and public relations studies of the Konya Metropolitan Municipality website are generally sufficient but have some deficiencies. As a result of the study, various suggestions were made to increase the quality of e-services and public relations works offered on the website and to eliminate the deficiencies identified.
\end{abstract}

Keywords: Konya Metropolitan Municipality, E-Municipality, E-Service, Website, Content Analysis

\footnotetext{
${ }^{1}$ Doç. Dr., Sivas Cumhuriyet Üniversitesi, Turizm Fakültesi, Turizm İşletmeciliği Bölümü, sukrankaraca@gmail.com (Sorumlu Yazar)

${ }^{2}$ Yüksek Lisans Öğrencisi, Sivas Cumhuriyet Üniversitesi, Sosyal Bilimler Enstitüsü, Turizm İşletmeciliği Ana Bilim Dall, baharcicek.gubul@gmail.com
} 
Kurumsal web sitelerinin işlevselliğinin, sunulan e-hizmetlerin ve halkla ilişkiler faaliyetlerinin içerik analizi yöntemiyle incelenmesi: Konya Büyükşehir Belediyesi web sitesi örneği, Ş., KARACA, B. Ç., GÜBÜL

\section{Giriş}

Bilgi ve iletişim teknolojileri sadece insanların iletişim kurma, çalışma ve yaşama biçimini değiştirmemiş aynı zamanda kamu kurumlarının vatandaşlarla olan ilişkisini de değiştirmiştir. Birçok kamu kurumu geleneksel hizmetlerini internete taşıyarak e-hizmetler aracılığılla vatandaşlar ile iletişimini internet üzerinden aktif bir şekilde gerçekleştirmektedir. Özellikle teknolojinin gelişmesi ile birlikte vatandaşların kamu kurumlarıyla olan iletişimleri çevrimdışı görevliler yerine çevrimiçi görevliler tarafından sağlanmaya başlanmıştır (Thiele, 2011, s.1-2). Hemen hemen tüm gelişmiş ülkelerdeki kamu kurumları, erişim, şeffaflık ve geliştirilmiş devlet hizmetleri ile vatandaşların çeşitli talepleri için kapsamlı e-devlet uygulamaları başlatmışlardır (Sayımer, 2015, s.2).

E-belediyecilik anlayışı, e-devlet uygulamasının yerel yönetimdeki birimlere yansımasıyla ortaya çıkmış bir kavramdır. E-belediyecilik uygulamaları ile belediyelerle vatandaş arasındaki iletişimi ve etkileşimi artıracak hizmetler sunulmaktadır. Sunulan hizmetlerin daha hızlı, etkili, kolay ulaşılabilir ve kaliteli olması belediyelerin geniş halk kitleleri oluşturması açısından önemli katkılar sağlamaktadır (Hazman, 2005, ss.66-67). Kişisel memnuniyetin büyük ölçüde sunulan hizmetlerin kalitesine bağl1 olduğu belediye faaliyetlerinde bilgi akışı ve özel sektör kuruluşları ile etkileşim, bireyler ve yerel yönetim birimleri arasında bilgi teknolojilerinin yardımıyla daha etkin bir şekilde yürütülebilmektedir (Daştan, 2015, s.104). Belediyeler için elektronik ortamda yerel hizmetlerin sağlanması bilgi teknolojileri aracıllğıyla devlet kurum ve kuruluşları, özel sektör kuruluşları ve vatandaşlarla etkileşim kurmak anlamına gelmektedir. E-belediye sistemi, yerel yönetimlerdeki günlük işlerin uygulanmasını kolaylaştırmaktadır. Kurulan güçlü veri tabanı sayesinde vatandaşlar web sitesi üzerinden birçok hizmete (borç sorgulama, ödeme vb.) ulaşabilmekte ve hizmetler çevrimiçi olarak sunulmaktadır. $\mathrm{Bu}$ sürecin sağlıklı işleyebilmesi için organizasyon hazırlığı, sistem ve hizmet hazırlı̆̆ı, altyapı hazırlığının uygulamadan önce iyi planlanması gerekmektedir (Bojang ve Bwando, 2018, ss.5-6).

Ulusal ve yerel yönetimler dijital bilgi alışverişinin sunduğu çeşitli firsatları giderek daha fazla kullanmaktadırlar. Son yıllarda kamu kurumları özellikle de belediyeler web siteleri aracılığıyla vatandaşlara daha yoğun bir şekilde e-hizmet sunmaktadırlar. Bu bağlamda Konya Büyükşehir Belediyesi'nin web sitesinin işlevselliğinin, sunulan e-hizmetlerin ve halkla ilişkiler faaliyetlerinin incelenmesi çalışmanın amacını oluşturmaktadır. Konya Büyükşsehir Belediyesinin web sitesinin incelenmesine yönelik daha önce çalışmalar yapılmış olmasına rağmen bu çalışmalar yapıldığında belediyelerin teknoloji kullanım düzeyleri daha kısıtlı iken günümüzde belediyeler internet ve bilgi teknolojilerini daha yoğun bir şekilde kullanmaktadır. Ayrıca bu çalışmada Konya Büyükşehir Belediyesi web sitesi e-hizmetler, tanımaya yönelik, tanıtmaya yönelik, hem tanımaya hem tanıtmaya yönelik halkla ilişkiler çalışmaları ve web sitesinin işlevselliği de dahil olmak üzere bütüncül bir bakış açısıyla ele alınmıştır. Bu yönüyle çalışmanın literatüre katkı sağlayacağı düşünülmektedir.

\section{Literatür taraması}

Teknolojinin özellikle de internet kullanımının yaygınlaşması, artan vatandaş talepleri, kurumsal imajın ve hizmet kalitesinin yükseltilme düşüncesi, kurumsal tanınırlığın arttırılması, halkla ilişkilerin daha etkin hale getirilmesi, önemli bilgilerin daha geniş kitlelerle paylaşılabilmesi, kamuoyu araştırmalarının daha az maliyetle ve etkin bir şekilde yapılabilmesi, toplam maliyetlerin azaltılması, tahsilat oranının yükseltilmesi, bürokrasi ve kırtasiyeciliğin azaltılması, yasal yükümlülüklerin yerine getirilmesi, katılım ve şeffaflık arzusunun artması ile kamu hizmetlerinin sunumundaki etkinliğin artırılması gibi unsurlar belediyeleri dijital dünyaya adım atmaya itmiştir (Mecek, 2017, ss.1816-1817). $\mathrm{Bu}$ unsurların belediye web sitelerinde ne ölçüde sunulduğu ile ilgili ise birçok çalışma yapılmıştır. Kaya Bensghir (2001, s.80) Konya Büyükşehir Belediyesi web sitesini incelediği çalışmasında birçok unsur (web sitesinin içeriği ve hizmet türleri, web politikası, web hizmetleri, url adresleri, referans/biyografi, arşiv, server'a erişim, güncellik, yabancı dil seçeneği, engelliler için erişim kolaylığı, site haritası vb.) açısından belediye web sitesini değerlendirmiştir. Çalışma sonucunda belediyenin web sitesini tek yönlü bir iletişim aracı olarak kullanıldığ ve daha fazla katkı sağlayabilecek unsurlara ve online hizmetlere de yer verilmesi gerektiğini ifade etmiştir. Yine Bensghir (2005) yaptığı çalışmada; İstanbul, Ankara, İzmir, Kocaeli, İzmit, Antalya ve Kayseri belediyelerinin web sitelerini analiz etmiştir. Araştırma sonucunda web sitelerinin e-hizmet sağlamaktan ziyade çoğunlukla tek taraflı basit bilgi aktarımı biçiminde olduğunu, web sayfalarının 
yöneticilerin isteklerine göre tasarlandığını, vatandaşların web sitelerinin yönetimine katılımını sağlamak veya teşvik etmek için herhangi bir uygulama olmadığını, belediyelerin internet sitelerinde elektronik ticaret uygulaması olmadığını, web sitelerinin uygulamalarının çoğunlukla halkla ilişkiler odaklı olduğu sonucuna varmıştır (Bensghir, 2005'ten aktaran Bojang ve Bwando, 2018, ss.9-10). Şahin (2007, s.185-186) tarafından Konya'daki tüm ilçe ve belde belediyelerinin e-belediye uygulamalarını tespit etmek amacıyla yaptı̆̆ çalışmada belediyelere ait bilgisayarların teknoloji düzeylerinin yeterli olmadığı, bilgisayar konusunda eğitimli yeterli elemanları olmadığı, belediyelerin teknoloji seviyelerini artırmak için yeterli bütçe ayırmadıkları/ ayıramadıkları, belediyelere vatandaşların internet üzerinden ulaşabilme imkânının çok kısıtlı olması, belediyeye ulaşan dilek ve şikâyetlere yanıt verilmemesi, belediyelerin web sayfalarının tanıtıcı birer broşür ya da halkla ilişkiler ağılıklı bir görünüm sergilediği, belediyelerin web sayfaları e-hizmet sunmaktan çok tek yönlü bilgi aktarımı olduğu, belediyelerde edönüşüm ile ilgili hizmet içi eğitim kurslarının ya yetersiz olması ya da bu konuda hiç kurs düzenlenmemesi gibi sonuçlara ulaşmışırı. Tanyıldızı ve Karatepe'nin (2011, ss.534-535) yaptıkları çalışmada ise, Türkiye ve Fransa'da bulunan iki kentin belediyelerinin web siteleri biçimsel, tanıma ve tanıtma yönünden halkla ilişkiler çalışmaları incelenmiştir. Çalışma sonucunda iki belediyenin de web siteleri biçimsel açıdan yeterli olmakla birlikte, birbirinden çok farklı olmadığı, tanıma ve tanıtma konusundaki web hizmetlerinin ise genel olarak yeterli görüldüğünü, web sitelerin halkla ilişkiler açısından bazı olumsuzlukları olduğunu tespit etmişlerdir. Şenyurt (2016, ss.57-58) tarafından yapılan çalışmada da Konya Merkez İlçe Belediyeleri'nden Meram, Selçuklu ve Karatay Belediyeleri'nin kurumsal web siteleri incelenmiş ve belediyelerin kurumsal web sayfalarını daha çok tanıtma amaçlı kullandığını tespit edilmiştir. Aynı zamanda belediyelerin bazılarının mobil uygulamalardan yararlanmadığ 1 , yararlanan belediyelerin uygulamalarında ise hem tanıma hem de tanıtma yönünden önemli eksikliklerin bulunduğu, bu açıdan uygulamaların her iki halkla ilişkiler faaliyeti açısından yetersiz olduğu ve belediyelerin kurumsal Twitter ve Facebook hesaplarından daha çok kamuyu bilgilendirme modeli çerçevesinde tek yönlü olarak yararlandığ 1 belirlenmiştir. Alat (2018, s.107) tarafından yapılan çalışmada da Türkiye'deki 51 ilin (Büyükş̧ehir Belediyeleri hariç) belediyesinin edevlet uygulamaları çerçevesinde geldikleri düzeyi belirlemek üzere belediye web sitelerinin işlevselliği değerlendirilmiştir ve belediye web sitelerinin işlevsellik açısından istenilen seviyede olmadığı sonucuna ulaşılmıştır.

Web sitelerinin incelenmesine yönelik çalışmalarda belediyelerin web sitelerindeki bazı problemler ve hatalar da araştırılmıştır. Bu hatalardan en yaygın olanlardan biri tek taraflı iletişimdir. Scott (2006, s.341) tarafından yapılan bir çalışmada da, web sitelerinin vatandaşlarla interaktif iletişim konusunda sınırlı bilginin mevcut olduğu ifade edilmiştir. Hunt (2007, s.155) tarafindan yapılan bir çalışmada; yaygın hatalardan biri olarak şehir liderlerinin siteyi izlememesi olarak ifade edilmiştir. Birçok belediye başkanı, yönetici ve meclis üyesi, şehir web sitesini nadiren ziyaret ettiklerini itiraf etmişlerdir. Aynı zamanda şehrin posta adresini şehir sitesinde bulmanın genellikle beş dakikadan fazla sürdüğ̈ vurgulanmıştır. E-belediye uygulamalarına engel olan nedenlerden biri de finansal kaynakların ve web personelinin eksikliğidir (Coursey ve Norris, 2008, s.523; Moon ve Norris, 2005, s.43). Belediyelerin web sitelerinde sık rastlanan bir başka hata da güncel olmayan bilgilerdir. Bazı belediyelerin web siteleri aylar hatta yıllar içinde güncellenmemiştir. Bu durum özellikle yalnızca "duyurum" bilgileri sunan web sitelerinde yaygındır. Vatandaşlar, web sitelerinden güncel bilgiler beklemektedir (Hunt, 2007, s.173).

Belediyelerin web sitesi inceleme çalışmalarının bazılarında da web sitesi ile ilgili sorunlar ele alınmıştır. Latif ve Masrek (2010, ss.9-10) yaptıkları çalışmada, web sitesi değerlendirmesi sırasında ortaya çıkan problemleri hız, kopuk bağlantı ve hata sayfası bulunamadı gibi kullanılabilirlik ve erişilebilirlik sorunu olarak bulmuşlardır. Ayrıca yapılan çalışmalar kopuk bağlantıların bir web sitesinin güvenilirliği üzerinde kötü etki yaratabileceğini de desteklemektedir (Huang vd., 2009, s.34). Detlor vd. (2013, s.23) tarafından yapılan çalışmada da belediyelerin web sitesi sorunlarından birinin düşük kullanım sıklığı olduğu ifade edilmiştir. Bu sorunun en önemli nedenlerinden birisinin ise bilgi kalitesi olduğu tespit edilmiştir.

Belediyeler hizmet kalitesini artırmak, iletişimi geliştirmek ve sorunları çözebilmek için web siteleri geliştirme çalışmalarına önem vermektedirler. Daştan (2015, s.111) Yalova e-belediyesi üzerinde yaptığı çalışmasında, teknoloji kullanımındaki yetkinlik, algılanan kullanım kolaylığı, 
algılanan farkındalık ve bilgi kalitesinin e-belediye hizmetlerinin kabulünü olumlu yönde etkilediği sonucuna ulaşmıştır.

\section{Araştırmanın amacı ve yöntemi}

Bu araştırmanın amacı, Konya Büyükşehir Belediyesi'nin web sitesinin işlevselliğinin, sunulan e-hizmetlerin ve halkla ilişkiler faaliyetlerinin içerik analizi yöntemiyle incelenmesidir. Araştırma amacı doğrultusunda geliştirilen araştırma soruları şu şekildedir:

1.Konya Büyükşehir Belediyesinin web sitesi işlevsel midir?

2.Konya Büyükşehir Belediyesinin sunduğu e-hizmetler nelerdir ve yeterli midir?

3.Konya Büyükşehir Belediyesinin halkla ilişkiler çalışmaları yeterli midir?

Araştırmada Konya ilinin incelenmesinin sebebi, Konya ilinin Büyükşehir olması ve sunulan hizmetlerin kapsamının geniş olmasıdır. Konya ilinin 2019 yılı nüfusu 2.232.374'dür (tuik.gov.tr, 2020). Çalışmada, araştırma yapılan bir konunun içeriğinin nesnel, sistematik ve nicel olarak anlaşılır şekilde açıklanması amacıyla içerik analizi yöntemi tercih edilmiştir (Yıldız, 2019, s.7). İçerik analizi, araştırmacıların elde ettiği verileri kolay bir şekilde gözden geçirmesini sağlayan bir yöntemdir. Bu çalışmada Tanyıldızı ve Karatepe (2011, s.528) tarafından kullanılan kodlama cetveli kullanılmıştır. Test güvenilirliğinin yüksek olması nedeniyle bu kodlama cetveli tercih edilerek Konya Büyükşehir Belediyesi' ne uyarlanmış ve bu cetvele çeşitli eklemeler de (sunulan e- hizmetler, tanımaya ve tanıtmaya yönelik halkla ilişkiler çalışmaları) yapılmıştır.

\section{Bulgular}

Bu kısımda Konya Büyükşsehir belediyesinin web sitesine erişim, web sitesinin genel görünümü, kullanım kolaylığı, sunulan e-hizmetler, tanımaya ve tanıtmaya yönelik halkla ilişkiler çalışmalarına yönelik bilgiler yer almaktadır:

Tablo 1. Belediye Web Sitesine Erişim ile Illgili Biçimsel Analiz Verileri

\begin{tabular}{|c|c|}
\hline SİTEYE ERIŞ̧іM & $\begin{array}{c}\text { KONYA BÜYÜKŞEHİR } \\
\text { BELEDİYESI }\end{array}$ \\
\hline Google arama motoruna yazıldı̆̆ında site bulunabiliyor mu? & Evet \\
\hline Google arama motoruna yazıldığında site kaçıncı sırada yer alıyor? & Birinci sırada yer alıyor \\
\hline Sitenin yüklenme süresi ne kadar? & 2 saniye \\
\hline
\end{tabular}

Kaynak: Konya Büyükşehir Belediyesi web sitesi (www.konya.bel.tr) esas alınarak araştırmacılar tarafından oluşturulmuştur.

Tablo 1'de, Konya Büyükşehir Belediyesi'nin web sitesine erişim ile ilgili biçimsel analiz verilerine yer verilmiştir. Tabloya göre, kullanıcılar hızlı ve kolay bir şekilde siteye erişim sağlayabilmektedir. 
Tablo 2. Belediye Web Sitesinin Genel Görünümü ile İlgili Biçimsel Analiz Verileri

\begin{tabular}{|c|c|}
\hline GENEL GÖRÜNÜŞ̧ & $\begin{array}{c}\text { KONYA BÜYÜKSEHİR } \\
\text { BELEDIYYESI }\end{array}$ \\
\hline Ana sayfa sade, açık ve anlaşılır mı? & Evet \\
\hline Sayfalarda renk kullanımı var mı? & Beyaz \\
\hline Zemin rengi nedir? & Hayır \\
\hline Fon müziği var mı? & Evet \\
\hline Sayfalar arası uyum var mı? & Uzun \\
\hline Sayfa uzunluğu & Evet \\
\hline Sayfa kenar boşlukları var mı? & Evet \\
\hline Tanıtma faaliyetlerinde fotoğraf kullanılmış mı? & İşler \\
\hline Sayfada butonların işlerliği & Evet \\
\hline Sayfalarda ikon(kücük simgeler) ve banner(reklam görseli) yoğunluğu & Evet \\
\hline $\begin{array}{c}\text { Yazılar okunabilir bir yazı karakteri ve punto büyüklüğü ile yazılmış } \\
\text { mı? }\end{array}$ & Evet \\
\hline $\begin{array}{c}\text { Sitedeki yazılar, resimler ya da diğer grafikler dengeli ve göze hoş } \\
\text { gelen biçimde mi? }\end{array}$ & Hayır \\
\hline kazıların arka planında metni okumaya engel olan renk ve desenler \\
kullanılmış mı?
\end{tabular}

Kaynak: Konya Büyükşehir Belediyesi web sitesi (www.konya.bel.tr) esas alınarak araştırmacılar tarafından oluşturulmuştur.

Tablo 2’de Konya Büyükşehir Belediyesi web sitesinin genel görünümü ile ilgili biçimsel analiz verileri yer almaktadır. Web sitesi açık ve anlaşıır bir görünüme sahiptir. Kullanılan renk tonları rahatsız edici değildir ve sitede gereksiz yazı ve resimlere yer verilmemiştir. Genel olarak web sitesi dikkat çekici bir görünüme sahiptir. Biçimsel olarak web sitesinin genel görünümünü bozacak herhangi bir olumsuzluğa rastlanmamıştır.

Tablo 3. Belediye Web Sitesinin Kullanım Kolaylı̆̆ ile İlgili Biçimsel Analiz Verileri

\begin{tabular}{|c|c|}
\hline KULLANIM KOLAYLIĞI & $\begin{array}{c}\text { KONYA BÜYÜKSSEHİR } \\
\text { BELEDIYYESI }\end{array}$ \\
\hline Ana sayfada site haritasıı var mı? & Evet \\
\hline Ana sayfadan diğer linklere ulaşmada sıkıntı var mı? & Hayır \\
\hline Sayfalar arası geçiş-bağlantı var mı? & Evet \\
\hline Her sayfada bir ana sayfa bağlantısı var mı? & Evet \\
\hline Arşiv/Arşive ulaşma imkânı var mı? & Kısıtlı \\
\hline Kelime, tarih, etkinlik olarak arama yapıılabiliyor mu? & Hayır \\
\hline Sayfadan çıktı alma imkânı var mı? & Hayır \\
\hline Dil seçim imkânı var mı? & Evet \\
\hline Sitede her pencerenin başlı̆ı̆ var mı? & Evet \\
\hline Online işlem var mı? &
\end{tabular}

Kaynak: Konya Büyükşehir Belediyesi web sitesi (www.konya.bel.tr) esas alınarak araştırmacılar tarafindan oluşturulmuştur.

Tablo 3'te Konya Büyükşehir Belediyesi web sitesinin kullanım kolaylığı ile ilgili biçimsel analiz verileri yer almaktadır. Verilere bakıldığında kullanıcılar site haritasında istenilen hizmete kolay bir şekilde ulaşabilmektedir. Sitede sayfalar arası geçiş yapılabilmekte ve her sayfada ana sayfaya dönüş sekmesi bulunmaktadır. Sitede verilen her hizmet ayrı bir başlık altında yer almaktadır. Arşive ulaşmada bir sıkıntı yaşanmamakta, geçmiş dönem verilerine kolay bir şekilde ulaşılmaktadır. Diğer verilere bakıldığında ise, sitede kelime ve etkinlik aramasında problem yaşanmazken tarih yazılarak yapılan aramada herhangi bir veriye rastlanmamıştır. Bir diğer sorun da dil seçeneğindeki eksikliktir. Türkçe 
dışında başka bir dil seçeneğinin olmaması yabancı ziyaretçilerin istedikleri bilgiye ulaşmasında sıkıntı yaratmaktadir.

Tablo 4. Belediye Web Sitesinin E-Hizmetler Açısından Incelenmesine Yönelik Analiz Verileri

\begin{tabular}{|c|c|}
\hline E-HiZMETLER & KONYA BÜYÜKŞEHİR BELEDIYYESI \\
\hline Sorgulama işlemleri & Var \\
\hline Elektronik ödeme hizmetleri & Var \\
\hline Evrak takip hizmeti & Var \\
\hline Online randevu işlemleri & Var \\
\hline Sosyal etkinlik sorgulaması & Var \\
\hline Hızlı ödeme sistemi & Yok \\
\hline Nöbetçi eczane sorgulaması & Var \\
\hline Borç sorgulama & Var \\
\hline Cenaze hizmetleri & Var \\
\hline İsyeri ruhsat işlemleri & Var \\
\hline Hal fiyatları/Semt pazarları & Var \\
\hline Nikâh hizmetleri & Yok \\
\hline Tarih ve zaman dilimine yönelik gerekçeli görüntü & Var \\
izleme talebi & \\
\hline Okul kayılt başvuru(uzaktan eğitim) & Var \\
\hline Okul hizmetleri başvurusu(taşıma) & Yok \\
\hline
\end{tabular}

Kaynak: Konya Büyükşehir Belediyesi web sitesi (www.konya.bel.tr) esas alınarak araştırmacılar tarafından oluşturulmuştur.

Tablo 4'te belediye web sitesinin e-hizmetler açısından incelenmesine yönelik analiz verilerine yer verilmiştir. Yapılan inceleme doğrultusunda Konya Büyükşehir Belediyesinin web sitesinde; sorgulama, elektronik ödeme, evrak takibi, online (çevrimiçi) randevu ve sosyal etkinlik sorgulamas1 gibi işlemlere yer verildiği görülmektedir. Sosyal etkinlik kapsamında web sitesi ana sayfasında "etkinlik bülteni" butonu yer almakta ve güncel etkinlikler buradan takip edilebilmektedir. Nöbetçi eczane sorgulaması, borç sorgulaması hizmeti, cenaze hizmetleri, işyeri ruhsat işlemleri, hal fiyatları/ semt pazarları ve gerekçeli görüntü izleme talebi konusunda hız ve sokak kameralarına erişim hizmetine yer verilmiştir. Sokak kameralarına erişim konusunda bir sıkıntı yaşanmamaktadır. Belediye web sayfasına giriş yapıldığında ana sayfada 'şehir kameraları' butonundan, 'trafik kameraları' ve 'turistik kameralar' şeklinde iki türlü hizmetin mevcut olduğu görülmektedir. Aynı zamanda Konya Büyükşehir Belediyesi pandemi sürecinde öğrencilere uzaktan eğitim kapsamında okul kayıt başvuru hizmeti sunmaktadır. Uzaktan ders kayıtları kapsamında meslek dersleri kaydı hizmeti sunulmaktadır. Ek hizmet olarak, çeşitli aktivitelere (yüzme dersi, spor(aerobik dersi)) belediye web sitesi üzerinden 'e-belediye' butonuna tıklayarak 'KOMEK veya ASEM' seçeneğinden bu hizmete ulaş1labilmekte ve ilgilenilen aktiviteye kolaylıkla kayıt yapılabilmektedir. Buna karşın eğitimin uzaktan olması sebebiyle taşıma konusunda öğrencilere hizmet sunmamaktadır. E-belediye butonunda yer alan Belediye Su ve Kanalizasyon İdaresi İnternet Şubesi (e-KOSKİ) hizmetleri içerisinde; fatura hareketleri, fatura düzeltme, yeni abonelik, abonelik iptali, su fiyatı hesaplama, arıza ve kaçak bildirimi, hizmet tarifeleri, depozito ücretleri ve ödeme noktaları gibi birçok konuda hizmet vermektedir. Ayrıca e-dilekçe ve e-kart (ulaşım kartı) gibi çevrimiçi hizmetlere e-belediye butonundan kolay bir şekilde erişim sağlanmaktadır. Konya Büyükşehir Belediyesi’nin web sitesi üzerinden sunmadığı hizmetler incelendiğinde ise, hızlı ödeme sistemi ve nikâh hizmetlerinin olmadığı görülmektedir. 
Tablo 5. Belediye Web Sitesinin Tanımaya Yönelik Halkla İlişkiler Çalışmaları Açısından Analizi

\begin{tabular}{|c|c|}
\hline TANIMAYA YÖNELİK ÇALIŞMALAR & KONYA BÜYÜKŞEHİR BELEDIYESI \\
\hline Anket var mı? & Evet \\
\hline Telefon, faks, e-mail var mı? & Hayır \\
\hline Şikâyet ve istek hattı var mı? & Evet \\
\hline Bilgi edinme seçeneği var mı? & Evet \\
\hline Başkana mesaj butonu var mı? & Hayır \\
\hline Ziyaretçi sayısı var mı? & Evet \\
\hline Sıkça sorulan sorular sayfası var mı? &
\end{tabular}

Kaynak: Konya Büyükşehir Belediyesi web sitesi (www.konya.bel.tr) esas alınarak araştırmacılar tarafından oluşturulmuştur.

Tablo 5'te Konya Büyükşehir Belediyesi web sitesinin tanımaya yönelik halkla ilişkiler çalışmaları açısından analiz verileri yer almaktadır. Belediyelerin vermekte olduğu hizmetler, iletişim araçlarının artmasıyla birlikte kolay erişilebilir hale gelmiştir. Belediyede yeni projelerin uygulamaya geçirilmesi aşamasında halka konuyla ilgili anket uygulamakta ve halkın görüşü alınmaktadır. $\mathrm{Bu}$ sayede belediye halkın hizmetlere olan bakış açılarıyla ilgili bilgi edinmekte ve iletişim ağını güçlendirmektedir. Telefon, faks gibi iletişim araçları aktif bir şekilde kullanılmaktadır. Sitede başkan bilgilerinin bulunması başkanla doğrudan iletişime geçme imkânı sağlamaktadır. Sitede 'sıkça sorulan sorular' sayfasının bulunması kullanıcılara site hakkında bilgi edinme firsatı sağlamaktadır. Bunlara karşın ziyaretçi sayısıyla ilgili bir bilgi bulunmamaktadır. Ziyaretçi sayısının görünürlüğü belediyenin web sayfasının işlevselliğini artırmak noktasında katkı sağlayacaktır. Genel olarak belediyenin iletişim araçlarını web sitesinde aktif bir şekilde kullandığı görülmüştür.

Tablo 6. Belediye Web Sitesinin Tanıtmaya Yönelik Halkla İlişkiler Çalışmaları Açısından Analizi

\begin{tabular}{|c|c|}
\hline TANITMAYA YÖNELIK ÇALIŞMALAR & $\begin{array}{c}\text { KONYA BÜYÜKŞEHİR } \\
\text { BELEDIYESİ }\end{array}$ \\
\hline Kurumun adı, logosu var mı? & Evet \\
\hline Kurumsal yapı var mı? & Evet \\
\hline Kurumun sorumlulukları ve amaçları var mı? & Evet \\
\hline Kurum yöneticileri var mı? & Evet \\
\hline Kurumun alt birimleri ve bu birimlerin görevleri var mı? & Evet \\
\hline Kurum ile alakalı mevzuat var mı? & Evet \\
\hline Kurumun sunduğu hizmetleri açıklayıcı sayfalar var mı? & Evet \\
\hline Eğer varsa sunulan etkileşimli hizmetler & Kısıtlı \\
\hline $\begin{array}{c}\text { Kurumun üretmekle yükümlü olduğu her tür rapor istatistiksel bilgiler var } \\
\text { mı? }\end{array}$ & Evet \\
\hline Basında kurum ile ilgili çıkan haberler, internet üzerinden sunulabilecek \\
her tür form var mı? & Evet \\
\hline Kuruma ait erişim bilgileri var mı? & Hayır \\
\hline Çalışanların iletişim bilgileri var mı? & Evet \\
\hline Şehre ulaşım bilgileri var mı? & Evet \\
\hline Ulaşım haritası var mı? & Hayır \\
\hline Bütçe stratejik plan var mı? & Evet \\
\hline İldeki turistik yerler butonu var mı? & Evet \\
\hline Kentteki nöbetçi eczaneler, sinemalar, festivaller vs. hakkında bilgi var \\
mı?
\end{tabular}

Kaynak: Konya Büyükşehir Belediyesi web sitesi (www.konya.bel.tr) esas alınarak araştırmacılar tarafından oluşturulmuştur.

Tablo 6'da Konya Büyükşsehir Belediyesi web sitesinin tanıtmaya yönelik halkla ilişkiler çalışmaları açısından analiz verileri yer almaktadır. Belediyenin web sitesi açıldığında sol üst köşede belediyenin adı ve logosu bulunmaktadır. Kurumsal başlı̆gı altında kurumda görev alan kadro ve belediyenin 
amblemi bulunmaktadır. Kurum yöneticileri, 'kurumsal yapı' başlığı altında bulunmaktadır. Hangi birimde kimlerin görev yaptığı belirtilmiştir. Kurumla ilgili mevzuat bilgisi, nöbetçi eczaneler, ihaleler, mezarlık bilgi sistemi ve tarımsal desteklemeler gibi hizmetleri içeren bilgiler 'interaktif' butonu altında yer almaktadır. Kurumun sunmakta olduğu hizmetler, 'hizmetler' ve 'e-belediye' butonu altında açıça ifade edilmektedir. Etkileşimli hizmet olarak çağrı merkezi hizmeti sunulmaktadır. Buradan vatandaşlar çağrı merkezi bilgilerine ulaşabilmektedir. Basında kurum ile ilgili çıkan haberler ana sayfada 'haberler' başlığ 1 altında gösterilmiş ve sosyal yardım formlarına yer verilmiştir. Kuruma ait her türlü iletişim bilgisi 'iletişim' butonunda yer almaktadır. Bu bilgiler kapsamında adres bilgileri, banka bilgileri, telefon rehberi, e-posta adresleri gibi hizmetler verilmektedir. Şehre ait ulaşım bilgileri 'hizmetler' butonu altında 'ulaşım hizmetleri' başlığı ile yer almaktadır. Ulaşım haritası 'kent bilgi sistemi' başlığı altında detaylı olarak gösterilmekte aynı zamanda 3D kent rehberi, 3D sanal tur ve imar planı portalı gibi bilgilere de yer verilmiştir. İlde gezilecek yerler 'hizmetler' başlığı altında 'Gez Konya'yı' şeklinde yer almaktadır. Ana sayfada bulunan 'Mevlana' butonunda; Mevlana'nın hayat1, dostları, eserleri ve Mevlevilik gibi konularda Mevlana'yı tanıtmaya yönelik çeşitli bilgilere yer verilmiştir. Bunlara karşın, kurumun sorumluluk ve amaçları ile ilgili herhangi bir bilgiye rastlanmamıştır. Web sitesi üzerinden kurum raporlarına ulaşmak sınırlıdır, rapor örneği olarak sadece itfaiye raporuna yer verilmiştir. İstatistiksel bilgilerde tablo ya da matematiksel gösterim bulunmamaktadır. Sitede bütçe ve stratejik planla ilgili bilgiler mevcut değildir. Ayrıca çalışanların iletişim bilgilerine de yer verilmemiştir.

Tablo 7. Belediye Web Sitesinin Hem Tanımaya Hem de Tanıtmaya Yönelik Halkla İlişkiler Çalışmaları Açısından Analizi

\begin{tabular}{|c|c|}
\hline TANIMA VE TANITMAYA YÖNELIKK & KONYA BÜYÜKŞEHİR BELEDİYESİ \\
ÇALIŞMALAR & Evet \\
\hline Basın ve halkla ilişkiler birimi var mı? & Evet \\
\hline Sosyal medya hesapları var mı? & Evet \\
\hline Mobil uygulamaları kullanıyor mu? & \\
\hline
\end{tabular}

Kaynak: Konya Büyükşehir Belediyesi web sitesi (www.konya.bel.tr) esas alınarak araştırmacılar tarafından oluşturulmuştur.

Tablo 7, Konya Büyükşehir Belediyesinin hem tanıma hem de tanıtma aracı olarak kullanabileceği halkla ilişkiler araçları açısından elde edilen verileri göstermektedir. Büyükşehir Belediyesi web sitesi üzerinde yer alan uygulamalarla gerçekleştirdiği ve gerçekleştireceği faaliyetler hakkında vatandaşları bilgilendirmekte, sosyal medya araçlarına yönelik yönlendirme linkleri sayesinde halkın görüş, öneri, istek veya şikâyetlerini alabilmektedir. Aynı zamanda vatandaşlar mobil uygulamalar sayesinde belediye hizmetlerini ve etkinliklerini kolaylıkla takip edilebilmekte ve bu uygulamalar sayesinde belediyeye kolayca ulaşabilmektedirler.

\section{Sonuç ve öneriler}

Bilgi ve iletişim teknolojilerinde yaşanan gelişmelere bağlı olarak belediyeler kaynak tasarrufu sağlamak, tahsilatı arttırmak, çok daha etkin, verimli, şeffaf, hukuka uygun, kesintisiz, demokratik ve katılımlı bir kamu hizmeti sunumu gerçekleştirebilmek için e-hizmet uygulamaları gerçekleştirmek zorundadırlar (Mecek, 2017). Bu nedenle son yillarda belediyeler web sitelerini vatandaşlara daha kaliteli ve daha iyi hizmet sunabilmek için daha etkin kullanmaya başlamışlardır. Bu kapsamda bu çalışma, Konya Büyükşehir Belediyesi'nin web sitesinin işlevselliğinin, sunulan e-hizmetlerin ve halkla ilişkiler faaliyetlerinin içerik analizi yöntemiyle incelenmesi amacıyla yapılmıştır. Çalışma kapsamında elde edilen bulgular şu şekildedir:

Konya Büyükşsehir Belediyesi web sitesini aktif bir şekilde kullanmaktadır. Belediyenin web sitesine erişme noktasında sitede yer alan ana sayfa ilk izlenimleri oluşturmakta ve kullanılan renk tonlamaları, dil, yazı puntoları ile bir bütün oluşturmaktadır. Aynı zamanda sitenin yalın ve anlaşıır olması halkın istediği bilgiye kolayca ulaşmasını sağlamaktadır. Büyükşehir Belediyesi web sitesine erişim kolay olmakla birlikte web sitesinin genel görünümü ve kullanım kolaylığı açısından da genel olarak olumsuz bir durum görünmemekte fakat web sitesinin sadece Türkçe hizmet vermesi bir sorun 
teşkil etmektedir. Bu durum yabancı ziyaretçilerin siteden yararlanmasını zorlaştırmaktadır. Yabancı dil olarak birçok ülkede ortak dil olarak kullanılan İngilizcenin ikinci bir dil seçeneği olarak siteye eklenmesiyle bu sorun giderilebilir.

Belediye web sitelerinde sunulmakta olan e-belediye hizmetlerinin birçoğuna Konya Büyükşsehir Belediyesi web sitesinden erişim sağlanmaktadır. Ancak web sitesi üzerinden hızlı ödeme sistemi, nikâh hizmeti konusunda e-belediye hizmetlerinin sunulmadığ tespit edilmiştir. $\mathrm{Bu}$ eksikliklerin giderilerek hizmet çeşitliliğinin artırılması e-belediyecilik kapsamında web sitesinin işlevselliğini artıracaktır.

Konya Büyükşehir Belediyesi web sitesi üzerinden sunduğu halkla ilişkiler faaliyetleri bakımından iyi bir durumdadır. Bu kapsamda engelli vatandaşlar da düşünülmüş ve 'EKPSS Kursu' hizmetine yer verilmiştir. Fakat bazı önemli eksiklikler mevcuttur. En önemli sorun şikâyet ve istek hattının olmamasıdır. Halkın hizmetler hakkındaki görüşlerinin geri dönüşümü sağlanamamaktadır. Sitede bulunan çağrı merkezi sayfasına istek ve şikâyet hattı eklenerek bu sorun çözülebilir. Aynı zamanda kurumun vizyon ve misyonuna yer verilmemesi önemli bir eksikliktir ve bu bilginin ana sayfada yer alması gerekmektedir. Ziyaretçi sayısının sitede yer almaması herhangi bir sorun yaratmamakta ama web sitesinin kullanımını artırmak için bu bilgiye de yer verilmelidir.

Elde edilen bulgular doğrultusunda Konya Büyükşsehir Belediyesi tarafından sunulan ehizmetlerin ve halkla ilişkiler çalışmalarının kalitesinin artırılması ve web sitesinin daha işlevsel olması için şu önerilerde bulunulabilir:

- Halkın istek, şikâyet, öneri ve görüşlerini belirlemeye yönelik sekmeler eklenmeli, bu talepler doğrultusunda belirlenen eksiklikler giderilmeli ve hizmet çeşitliliği artırılmalıdır.

- Tanıma ve tanıtmaya yönelik halkla ilişkiler çalışmalarında kullanılacak uygulamalar teknolojiyle uyumlu olarak artırılmalıdır.

- Web sitesi üzerinden halkın belediye hizmetleri hakkında ne düşündükleri ve beklentileri ile ilgili anketler yapılmalıdır.

- Sosyal medya hesapları interaktif iletişim sağlayacak şekilde kullanılmalıdır.

- Vatandaşların işlemlerini mobil uygulama üzerinden kolay ve hızlı bir biçimde gerçekleştirmelerine imkân verecek uygulamalar geliştirilmelidir.

Son olarak bu çalışmanın kısıtlarına değinilecek olursa; çalışma tek bir il ile sınırlı tutulmuş ve nitel yöntemler kullanılmıştır. Gelecek çalışmalarda diğer belediyelerin web siteleri ile karşılaştırmalı analizler yapılabilir. Ayrıca vatandaşların web sitesi üzerinden sunulan e-hizmetler, halkla ilişkiler çalışmaları ve web sitesinin işlevselliği hakkındaki görüşleri nicel yöntemler kullanılarak değerlendirilebilir. 


\section{KAYNAKÇA}

Alat, B. (2018). Türkiye'de il belediye web sitelerinin işlevselliği üzerine bir araştırma. Firat Üniversitesi Sosyal Bilimler Dergisi, 28(1), 93-114.

Bojang, M. B., \& Bwando, W. (2018). E-municipality applications in local government: Prospects and challenges [Konferans sunumu]. 1st International Conference on New Approaches in Social Sciences and Humanities, https://bib.irb.hr/datoteka/945965.01_a2.pdf

Coursey, D., \& Norris, D. F. (2008). Models of e-government: Are they correct? An empirical assessment. Public Administration Review, 68(3), 523-536.

Daştan, İ. (2015). Digitalizing the municipality and factors affecting the acceptance of e-municipality: An empirical analysis. International Business Research, 8(12), 104-115.

Detlor, B., Hupfer, M.E., Ruhi, U., \& Zhao, L. (2013). Information quality and community municipal portal use. Government Information Quarterly, 30(1), 23-32.

Hazman, G. G. (2005). Afyonkarahisar Belediyesinde e-belediye uygulamaları ve yerel farkındalık. Afyon Kocatepe Üniversitesi İktisadi ve İdari Bilimler Fakültesi Dergisi, 7(2), 6584.

Huang, Z., Brooks, L., \& Chen, S. (2009). The assessment of credibility of e-government: Users perspective. Salvendy,G. ve Smith, M. J. (Ed.) içinde. Human ınterface and the management of information. Information and Interaction (ss. 26-35). Berlin: Heidelberg.

Hunt, J. (2007). The whole-of-government experiment in indigenous affairs: A question of governance capacity. Public Policy, 2(2), 155-174.

Kaya Bensghir, T. (2001). Web'deki belediyelerimiz: Konya Büyükşehir Belediyesi. Çağdaş Yerel Yönetimler Dergisi, 10 (4), 80-95.

Konya Büyükşehir Belediyesi Web Sitesi (2020, Kasım). https://www.konya.bel.tr/

Latif, M. H. A., \& Masrek, M. N. (2010). Accessibility evaluation on Malaysian e-government websites. Journal of E-Government Studies and Best Practices, 1-11.

Mecek, M. (2017). E-devlet ve e-belediye: Kavramsal çerçeve ve Türkiye'de belediye web sitelerine yönelik yapılan çalışmaların incelenmesi. Süleyman Demirel Üniversitesi İktisadi ve İdari Bilimler Fakültesi Dergisi, 22, 1815-1851.

Moon, M. J., \& Norris, D. F. (2005). Does managerial orientation matter? The adoption of reinventing government and e-government at the municipal level. Information Systems Journal, 15(1), 4360.

Sayımer, İ. (2015). Electronic government in public administration: An assessment of local government web sites in Turkey. International Journal of E-business and E-government Studies, 7(2), 1-16.

Scott, J. K. (2006), "E" the people: Do U.S. municipal government web sites support public involvement? Public Administration Review, 66(3), 341-353.

Şahin, A. (2007). Türkiye'de e-belediye uygulamaları ve Konya örneği. Erciyes Üniversitesi İ̈BF Dergisi, 29,161-189.

Şenyurt, G. (2016). Belediyelerin halkla ilişkiler uygulamalarında internetin ve sosyal medyanın kullanımı: Konya merkez ilçe belediyeleri üzerine bir inceleme. İnönü Üniversitesi İletişim Fakültesi Elektronik Dergisi, 1(1), 44-67.

Tanyıldızı, N. İ., \& Karatepe, S. (2011). Belediyelerin halkla ilişkiler çalışmalarında web siteleri: İki farklı ülke ve iki farklı belediye analizi. E-Journal of New World Sciences Academy (Nwsa), 6(3), 520-538.

Thiele, L. (2011). Online government: An analysis of municipal websites in the United States, University of Nebraska at Omaha. 
Kayseri Üniversitesi Sosyal Bilimler Dergisi, Cilt 2, Sayı: 2, Aralık 2020, 55-65

Kayseri University Journal of Social Sciences, Vol 2, No: 2, December 2020, 55-65

Türkiye İstatistik Kurumu. Nüfus İstatistikleri (2020). https://www.tuik.gov.tr/

Yıldız, İ. (2019). Belediyelerin iletişim çalışmaları kapsamında web sitesi kullanım durumları (Bingöl Belediyesi web sitesine yönelik bir içerik analizi). Istanbul Sosyal Bilimler Dergisi, 23, 1-16. 